[4] Chunga MK, Leeb I, Keec D. Effect of stool height and holding time on postural load of squatting postures. In Tinatigon $2003,32,309-317$.

Prospective Study of $\mathrm{Neck}$, shoursted M. A Back Pain among Technical School Students Entering Working Life. J Adolesc Health 2010:

6] Hurwitz EL, Aker PD, Adams AH, Meeker WC, cenvical spine: a Sys Rev of the literature. Spine 1996;21 (15): :1746-59.

7] Benyamin R, Singh V, Parr AT, Conn A, Diwan S, Ab Epidurals in the Management of Chronic Neck Pain J Headache Pain 2009:12:137-157.

8] Robbins $M$, Johnson $\mathbb{I P}$, Cunliffe $C$. Encouraging Cod posture in school childen using computers.

Measurement of Cervical Posture Plane. J Manipulative Physiol Ther 2008:31(7)

Selwyn $\mathrm{N}$. The effect of using a home computer on inal use of IT.J Med Internet Res

1] Gold JE, Driban JB, Yingling VR, Komaroff. and comfort in laptop Ergonomics Society 201 1:43(2):392-9.

(12] Posture and Study Habitis Guide. McKinley Health Center Universily of linolis. 2008.Retrieved from

Grieco A. Sitting posture: an old problem and a new

(14] Strake Ergonomics 1986,29.345-362. and computer use in adolescents: the importance of gender, Ergonomics 2011;54(6):539.
15] Parcells C, Hubbard MS. Mismatch of classroom furniture and student body dimensions: Empirical findings and health implications; J Adolesc Health

[16] Smith L, Louw Q, Crous L Grimmer-Somers K. Prevaence of neck pain and headaches: impact of computer use and other associative factors Cepha-
lalgia 2009:29. (2): $250-257$

[17] Edmondston SJ, Chan YH, Ngai GCW, Warren MLR Williams JM, Netto SGK. Postural neck pain: An investigation of habitual sitting posture perception of 'good' posture and cervicothoracic kinaesthe

8] Cook C. Burgess-Limerick P The -

support on musculoskelet

[19] Chiung-Yu Cho, Survey of faulty postures and associated factors antong Chinese adolescents

20] Murphy S, Buckle P, Stubbs D. Classtoom posture children. Appl Ergon. 2004:35(2):113-20

of Statistics. Children's Austrila Report Number: 4901 O. Canberra AC: Australian Bureau of Statistics; $2012 \mathrm{http}: / / \mathrm{wm}$ w.abs.gov.au/ausstats/absa.nst/201/4901.0 Scandanavian J Rehabil Med 1988:20:175-9.

23] Dockrell S, Earle D, Galvin R. Computer-related posture discomfort in primary school children: The Med Internet Res 2010:55:276-284

24] Hojat B and Mahdi E. Effect of different sitting posture on pulmonary function in students. J Physio

[25] Murphy S, Buckle P, Stubbs D. Classroom posture and selfereorted back and Ergonomics 2004:35: 113-120
dren.

\section{ANALYSIS OF FACTORS LEADING TOWARDS OBESITY AMONG SCHOOL - GOING CHILDREN (AGED 13 - 16 YEARS) OF KARACHI}

\section{ABSTRAC}

OBJECTIVES

To analyze the factors leading to obesity in school children and to assess the role of Physical therapist in health education in schools

METHODS

It was a cross sectional study and factors leading towards obesity among school selected from different schools of Karachi through Convenience sampling technique. Data entry was done on SPSS version 20 and frequencies and

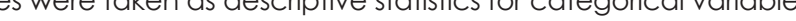

RESULTS

Din were included in the study where girls were $53.7 \%$ and boys were $46.3 \%$. It was found that majority $40 \%$ of the children come under the category of normal BMl while $37 \%$ were overweigh and obese. In adalion, $55 \%$ find out that $46 \%$ students were not participating in any physical activity and $45 \%$ schools didn't even had the PT period in their schedule. Furthermore, $91 \%$ students were consuming regularly.

CONCLUSIONS

Our study concluded that the major risk factor of obesity in 13-16 years children age group. Furthermore whest of our children are having less sleep than recommended which itself has a very strong relation with weight gain. 


\section{INTRODUCTION}

Worldwide childhood obesity is a considerable health challenging issue in developing countries like Pakistan $n^{3.5}$ WHO estimate that out of 1 billion overweight people in the world 300000 are obese ${ }^{67}$. In the past a fat child was considered to be a healthy one but now obesity and ove be responsible for many health probecms in may childhood and adult hood. Obesity is associated with the onset of many diseases like diabetes mellitus, hypertension, dyslipidemia, polycystic ovarian disease, atheroscle-
rosisis.10 and psychosocial problem 1.1112. have shown that obesity may be responsible for the

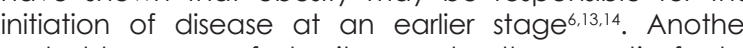
probable cause of obesity may be the genetic factor and life stylers. A major problem which has been identisedentary life style, which itself is responsible in grea majority for the incidence of obesity. Like outdoor games are replaced by computer and TV, junk food has become

A lot of work has been done on childhood obesity worldwide and in Pakistan. Recently, in 2012 a survey was conducted in Karachi children to determine the time survey revealed that most of the chilren were spending only half an hour in physical activities among which the majority was boys' ${ }^{16}$. According to the recommendation for the Asia pacific population B.M.l, greater than $23 \mathrm{~W}$ 25 will be taken as obese rather than a usual B.M. reference. In recent study using Indo-Asian specific cutoff values it is shown that quarter of Pakistan population would be counted as overweight and obese. Girls aged TV as compared to boys therefore are more prone to develop obesity's. In another study taking the B.M.I greater than 25 as obese 14 the prevalence of obesity was with the figure in the westol. National health survey of Pakistan 1990-94 and the Karachi survey 2004-05 reported prevalence of overweight in urban school children to be $3 \%$ and $5.7 \%$ respectively ${ }^{3}$. One of the major reason of overweight and obesity in school going children was due
to decline in physical activity'tis.

Obesity is hard to reverse once established $d^{17-19}$. The risk of childhood overweight will continue into adolescence people in near future will be difficult to tackle. Timely preventive measures in children and adolescence will be sound and effective way of dealing with problem of obesity. School is the place where children spend half of the day including regular physical activity in the curriculum can be one of the benefits that can be reaped through this intervention. Family environment and parental characteristics such as parental working status sibling,
person living in the child room etc must be considered in designing the strategies and intervention as it has strong influence on childhood obesity3. This study is focused to identify the various risk factors leading to overweight and
obesity and to evaluate the role of Physical therapist in health education in schools.

\section{MATERIAL AND METHODS}

A cross sefional survey was conducted in school going different schools of Karachi. A total of 300 students were selected through convenience sampling technique.

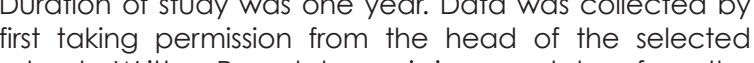
Warental permission was taken from the

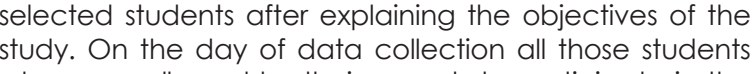
who were allowed by their parents to participate in the weight measurement through calibrated weighing scale and height chart. BMI was calculated by using the standard formula of wt in $\mathrm{kg} /$ height in meter square. A self administered questionnaire in both English and Urdu was about their routine activities, type of diet they are taking number of meals/day, type of exercises they do, about physical activity in their schools and engagement in any sports activity. They were further asked about family history of obesity
factors of obesity.

Data entry and analysis was done on SPSS version 20. Descriptive statistics were taken out for categorica

\section{RESULTS}

total of 300 participants were included in the study where number of girls and boys were almost equal
Imale $=46.35 \%$ and female $=53.7 \%$, The children were incorporated from the schools in Karachi, aged between 13-16 years from different areas. At the time of recruitment of factors leading to obesity. The height and weight of the individuals were taken to calculate the B.M.I. An awareness session for health and obesity was also
incorporated and for that brochures were distributed

\begin{tabular}{|c|c|c|}
\hline BMI & Frequency & Percent \\
\hline Underweight & 67 & 22.3 \\
Normal & 121 & 40.3 \\
Overweight & 97 & 32.3 \\
Obese & 15 & 5.0 \\
Total & 300 & 100.0 \\
\hline \multicolumn{2}{|c|}{ It was found that majority 40\% of the children come under }
\end{tabular}
$22 \%$ were underweight and only $5 \%$ were found to be obese.

When asked about number of meals they take in a day $5.7 \%$ were eating 5 meals a day.

\begin{tabular}{|c|c|c|}
\hline $\begin{array}{l}\text { No. of time taking } \\
\text { meal }\end{array}$ & Frequency & Percent \\
\hline 2 times & 46 & 15.3 \\
3 times & 101 & 33.7 \\
4 times & 136 & 45.3 \\
5 times & 17 & 5.7 \\
Total & 300 & 100.0 \\
\hline
\end{tabular}

On a question regarding the fast food consumption $40 \%$ children responded as occasionally, $30 \%$ stated rarely and $21.7 \%$ gave positive respons
Only $8 \%$ responded in negation.

\begin{tabular}{|c|c|c|}
\hline Eating fast food & Frequency & Percent \\
\hline & & \\
none & 23 & 7.7 \\
rarely & 90 & 30.0 \\
occasionally & 120 & 40.0 \\
frequently & 65 & 21.7 \\
Total & 300 & 100.0 \\
\hline
\end{tabular}
It was observed that $48 \%$ children rarely took hawker's
food, $24 \%$ avoided hawkers food while few stated occa
sidally

\begin{tabular}{|c|c|c|}
\hline Hawkers food & Frequency & Percent \\
\hline none & 72 & 24.0 \\
rarely & 143 & 47.7 \\
occasionally & 65 & 21.7 \\
frequently & 20 & 6.7 \\
Total & 300 & 100.0 \\
\hline
\end{tabular}

Regarding daily water intake $42.3 \%$ children were drinking 6 glasses of water per day, $28 \%$ said more than 6 glasses water per day.

\begin{tabular}{|c|c|c|}
\hline Daily water intake & Frequency & Percent \\
\hline less than 4 glasses & 7 & 2.3 \\
4 glasses & 81 & 27.0 \\
6 glasses & 127 & 42.3 \\
more than 6 & 84 & 28.0 \\
glasses & 300 & 100.0 \\
Total & \\
\hline
\end{tabular}

When inquired about physical training period $53 \%$ of children have PT session, while other doed

\begin{tabular}{|c|c|c|}
\hline $\begin{array}{c}\text { physical training } \\
\text { period in time } \\
\text { table }\end{array}$ & Frequency & Percent \\
\hline yes & 159 & 53.0 \\
no & 136 & 45.3 \\
Total & 300 & 100.0 \\
\hline
\end{tabular}

In response to TV watching habits, $36 \%$ claimed to spent
more than 2 hrs, 25\% spent more than 4 hours while others spent hour or more.

\begin{tabular}{|c|c|c|}
\hline watching T.V in a day & Frequency & Percent \\
\hline just $1 \mathrm{hr}$ & 50 & 16.7 \\
more than $1 \mathrm{hr}$ & 67 & 22.3 \\
more than $2 \mathrm{hr}$ & 107 & 35.7 \\
more than $4 \mathrm{hr}$ & 76 & 25.3 \\
Total & 300 & 100.0 \\
\hline
\end{tabular}

It was observed that $55 \%$ of the children have the positive
family history of obesity, while $45 \%$ did not have obesity in their family.

\begin{tabular}{|c|c|c|}
\hline $\begin{array}{c}\text { Family history of } \\
\text { obesity }\end{array}$ & Frequency & Percent \\
\hline yes & 165 & 55.0 \\
no & 135 & 45.0 \\
Total & 300 & 100.0 \\
\hline
\end{tabular}

When enquired about perception of why children tend to as major cause of obesity while $48 \%$ considered improper diet. In others opinion family history (41\%), improper sleep
and medications were also the reasons for getting and me
obesity.

\begin{tabular}{|c|c|c|}
\hline $\begin{array}{c}\text { Reasons of obesity in } \\
\text { children prospective }\end{array}$ & Frequency & percentage \\
\hline $\begin{array}{c}\text { lacking physical } \\
\text { activity }\end{array}$ & 153 & $51 \%$ \\
having improper diet & 145 & $48.3 \%$ \\
family history & 123 & $41 \%$ \\
improper sleeping & 83 & $27.7 \%$ \\
pattern & 12 & $4 \%$ \\
taking medications & 12 & \\
\hline
\end{tabular}

On a question regarding physical activity participation in different sports and $13 \%$ performed different exercises.

\begin{tabular}{|c|c|c|}
\hline $\begin{array}{c}\text { Engage in physical } \\
\text { activity }\end{array}$ & Frequency & Percent \\
\hline yes & 163 & 54.3 \\
no & 137 & 45.7 \\
Total & 300 & 100.0 \\
\hline
\end{tabular}

DISCUSSION

It is well know that obesity and overweight are associated with many risk factors such as improper dietary patterns, family history, physical inactivity and sedentary life style
lack of exercise, watching television or prolonged seated work etc. In the study we conducted, out of 300 children obese (5\%). In our study the frequency of overweight children was found to be high, $32.2 \%$, when compared to
the similar study conducted in Lahore, Pakistan which the similar study conducted in Lahore, Pakistan which
revealed $17 \% \%^{20}$. The recent increase may be due to the increased commercials of fast foods and transformation 
of active lifestyle to sedentary life style as in west. Even the studies conducted outside Pakistan shows lower
incidence of overweight children as shown by the results children rotio was $9.1 \%$ and in Tunis where the rerweight $19.7 \% \%^{21.22}$. The frequency of obesity is however similar to the study in Tunis $(5.7 \%)^{2}$

Regarding junk food consumption our research showed study conducted in Karachi in 2008 showed $80 \%$ children as junk food consumers'23. Our research also revealed tha children lack the physical training and $45.3 \%$ school didn't even had a physical training period as schedule. not participate in physical activity while $63.6 \%$ girls also said that they do not take part in physical activities. A similar study advocated $81 \%$ obese boys and $78 \%$ obese
girls do not affiliate themselves with physical activity 24 It it well understood that the major reason for putting on weight is high calorie intake and low output which is reflected in our society as obese and overweigh a days we are having high calorie diets (junk food) bu less physical workout indicating the lifestyle conversion into sedentary one. Sedentary pattern of life style promotes leisure activities which are unhealthy, such as using computer excessively, playing video games an get heavy advertisement adds of candies, snack food and sweetened breakfast cereals that are rich in calories and fats and lower in fiber and nutrients hence influencalso interesting that half of our study population has positive family history Hereditary contributes a major role as shown in several studies like in 2008 a study proclaimed for about $5-40 \%$ risk for obesity when parents were chance that a child will be overweight if both parents are obese and 20-50\% chance if only single parent is obese. Another factor contributing to weight gain is sleepless more than 8 hours sleep. This finding is also somewhat close to another study, conducted in the City of Trois-Rivières (Québec) in $20062^{25}$ which stated $23.1 \%$ boy who
sleeps 8-10 hours and 20.8\% girls were obese and sleeps $8-10$ ch
overweight.

\section{CONCLUSION}

Our study concluded that the major risk factor of obesity important to see that the usage of junk food is increasing in this age group that may be due to the enormous advertisement of junk stuffs. Another reason is the preference of relaxed/sedentary life style which is causing this important part and our research also revealed that most of our population earries obesity in its genes. One very important finding is about the sleep pattern which has a

\section{REFERENCE}

[1] Gupta K, Shah P, Mishra A, Bharadwaj S et al. obesity from 2006-2009 in urban Asian an adolescents aged 14-17 years. JPMC 2011.doi:10.1371/journal. pone.0017221. [available online]
info\%3Adoi\%2F10.1371\%2Fijournal.pone. 0017221

[2] Frayling MT, Nicholas J. Timpson, NJ Weedon MM. A
A Common Variant in the FTO Gene Is Associated with Body Mass Index and Predisposes
and Adult Obesity 2007:316: 889-894.

[3] Mushtaq MU, Gull S, Abdullah HM, Shahid U, Shad correlates of . Prevalence and socioeconomic Pakistani primary school children. BMC Public Health 201 1; 11:724 doi:10.1186/1471-2458/11/724 Mellitus in Pakistan: Issues and Challenges for Health Care Providers, JLUMHS 2010;9(3):231-34.

[5] Mickey Chopra, Sarah Galbraith \& Ian Darnton-hil A global response to a global problem: the epidemic of overnutrition

[6] Warraich HJ, Javed F, Faraz-Ul-Haq M, Khawaja FB, Saleem S. Prevalence of Obesity in School-Going
Children of Karachi. PLoS ONE 2009:4(3):e4816.

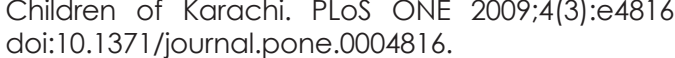

diet, physical activity and health 2003 . Volume 376 Issue 9754, 20-26 November 2010, Pages 1775-1784 Hoeger WK \& Hoeger A principal and labs for fitness
and wellness. 6th Ed. USA: wadsworth; 2010.202-05. Levy TS, Raun CM, Castellanos CA, Coronel As Aguilar AJ, Humaranl MG. Effectiveness of a dief and physical activity promotion strategy on the prevention of ablichly health $2012: 12: 152$
BMC doi:10.1 186/1471-2458/12/152.

[10] Halpern A, Mancini CM, Magalhães CE. Metabolic syndrome, dyslipidemia, hypertension and type 2 licensee Biomed Central Ltd 2010:2 2:55 doi:10.1186/1758-5996-2-55

[11] Aronne LJ, Segal KR. Weight Gain in the Treatment of Mood Disorders. Journal of Clinical Psychiatry

the Management of Weight Critical Product for Food Science and Nutrition 2002;42:163-178

13] Wahba M, Mak H. Obesity and Obesity-lnitiated Metabolic Syndrome: Mechanistic Links to Chronic
Kidney Disease climical journal of american society of nephrology 2007;2:550-562

14] American Obesity Association. 2002. What obesity? Retrieved September 25, 2006, from
http://www.obesity.org/information/what is_obesity.asp $\mathrm{F}$ Nicholas $\mathrm{J}$. Timpson NJ, Weedon MM. A Frayling MT, Nicholas J.T Timpson NJ, Weedon MM.A
Common Variant in the FTO Gene Is Associated with Body Mass Index and Predisposes to Childhood and 2007:316: 889-894

[16] Jafar TH, Qadr Z1, Islam M, Hatcher J, Bhutta ZA, Chaturvedi N. Rise in childhood obesity with persistently high rates of under nutrition among urban 2008:93:373-378 doi:10.1136/Adc 2007.125641. Available from :http://adc.bmj.com/content/ 93/5/373.ful

[17] Pletzer K, Pengpid S. Overweight and obesity and associated factors among school aged
adolescents in Ghana and Ugenda. Inj Environ Res public health 2011:8,3859-3870 doi:10.3390/jerph8103859.

18] Peltzer K., Pengpid S. [homepage on the Internet].
2011 cited 2012 Ju 2 Available from: htp

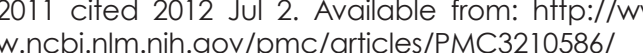

[19] Waters E. Interventions for preventing obesity in
children. Review. The Cochrane Libran children Review. The Cochrane Libray
2011;(2):1-70. between short sleeping hours and childhood

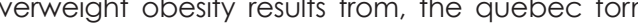
project. Interna

政, Gabsi Z, Bouslah A, Maalell. Risk factor of children overweight and obesity. Tunis Med 2012 May,90(5).387-93.

Lam L, MazighMrad S, Ben Hassine A, Bouyahia O, Zovari B. Prevalence and risk factors of overweight and obesity in elementary schoo children in 201 mentrop (1):50-4
[23] Warraich HJ, Javed F, Faraz-Ul-Haq M, Khawaja FB, Saleem S Prevalence of Obesity in School-Going
Children of Karachi. PLoS ONE 2009;4(3):e4816. doi:10.1371/journal.pone.0004816.

24] Childhood Obesty Assistant Secretary for Planning and Evaluation ASPE.hhs.gov US department of hitp://aspe.hns.gov/heallh/reports/child_obesity/ available online at: ic.com/health/childhood-obesity/ DSO0698/DSECTION=risk-factors 